\title{
Content of selected elements and low-molecular-weight organic acids in fruiting bodies of edible mushroom Boletus badius (Fr.) Fr. from unpolluted and polluted areas
}

\author{
Miroslaw Mleczek $^{1} \cdot$ Zuzanna Magdziak $^{1} \cdot$ Monika Gąsecka $^{1}$ • \\ Przemyslaw Niedzielski ${ }^{2}$ - Pavel Kalač ${ }^{3}$ Marek Siwulski ${ }^{4}$ - Piotr Rzymski ${ }^{5}$. \\ Sylwia Zalicka ${ }^{1} \cdot$ Krzysztof Sobieralski $^{4}$
}

Received: 10 January 2016 / Accepted: 8 July 2016 / Published online: 28 July 2016

(C) The Author(s) 2016. This article is published with open access at Springerlink.com

\begin{abstract}
The aim of the study was to (i) investigate the potential of edible mushroom Boletus badius (Fr.) Fr. to accumulate 53 elements from unpolluted acidic sandy soil and polluted alkaline flotation tailing sites in Poland, (ii) to estimate the low-molecular-weight organic acid (LMWOA) profile and contents in fruit bodies, and finally (iii) to explore the possible relationship between elements and LMWOA content in mushrooms. The content of most elements in fruiting bodies collected from the flotation tailings was significantly higher than in mushrooms from the unpolluted soils. The occurrence of elements determined in fruiting bodies of B. badius has been varied (from $0.01 \mathrm{mg} \mathrm{kg}^{-1}$ for $\mathrm{Eu}, \mathrm{Lu}$, and Te up to $18,932 \mathrm{mg} \mathrm{kg}^{-1}$ for K). The results established the high importance of element contents in substrate. Among ten organic acids, nine have been found in wide range: from
\end{abstract}

Responsible Editor: Philippe Garrigues

Electronic supplementary material The online version of this article (doi:10.1007/s11356-016-7222-z) contains supplementary material, which is available to authorized users.

Mirosław Mleczek

mirekmm@up.poznan.pl

1 Department of Chemistry, Poznan University of Life Sciences, Poznań, Poland

2 Faculty of Chemistry, Adam Mickiewicz University in Poznań, Poznań, Poland

3 Department of Applied Chemistry, Faculty of Agriculture, University of South Bohemia, České Budějovice, Czech Republic

4 Department of Vegetable Crops, Poznan University of Life Sciences, Poznań, Poland

5 Department of Biology and Environmental Protection, University of Medical Sciences, Poznan, Poland below $0.01 \mathrm{mg} \mathrm{kg}^{-1}$ for fumaric acid to $14.8 \mathrm{mg} \mathrm{g}^{-1}$ for lactic acid. Lactic and succinic acids were dominant in both areas, and citric acid was also in high content in polluted area. The correlation between element contents and the individual and total content of LMWOAs was confirmed.

Keywords Edible mushroom $\cdot$ Boletus badius $\cdot$ Underlying substrate $\cdot$ Contamination $\cdot$ Mineral composition $\cdot$ Flotation tailings $\cdot$ Soil $\cdot$ Organic acids

\section{Introduction}

Boletus badius (Fr.) Fr. (current name: Imleria badia (Fr.) Vizzini) is one of the most common, widely consumed edible wild mushroom species in European forests. Its ability to accumulate various elements in fruiting bodies collected from both unpolluted (Borovička and Řanda 2007; Malinowska et al. 2004; Rudawska and Leski 2005; Svoboda and Chrastný 2008) and polluted areas (Svoboda et al. 2006; Niedzielski et al. 2013) has been described in numerous studies (Kojta et al. 2012; Malinowska et al. 2004; Mleczek et al. 2015a; Reczyński et al. 2013). It is worth underlining that this species is capable of growing on extremely polluted sites (Mleczek et al. 2015b); however, trace element contents were usually reported in fruiting bodies collected from various unpolluted areas. Unfortunately, very few works comparing $B$. badius fruiting bodies collected from significantly different ecosystems as regards their ability to accumulate various elements are available (Kojta et al. 2012; Mleczek et al. 2015b). Data on multielemental analysis of B. badius are very scarce (Falandysz et al. 2001). According to a review of Kalač (2010), there are limited data on the content of selected elements such as $\mathrm{B}, \mathrm{Ga}, \mathrm{Li}, \mathrm{Tl}$, or $\mathrm{Sn}$. One reason for this scarcity is a lack of analytical possibilities 
(Falandysz 2008). Additionally, the question as to the significance of $\mathrm{pH} / \mathrm{Eh}$ conditions in element accumulation in mushroom fruiting bodies has yet to be explained, because such information is minimal (Falandysz and Borovička 2013). An increase/decrease of substrate $\mathrm{pH}$ modulates the bioavailability of most elements; therefore, the low-molecular-weight organic acids present in plants (Kutrowska and Szelag 2014) can play a significant role, where their focus is shifted to the influence of elements on defense mechanism (detoxicative and antioxidative), metal chelation, accumulation, and sequestration. However, to our knowledge, such information in relation to mushroom bodies has yet to be elucidated, and currently, information regarding the acids present in mushrooms only relates to their antioxidant properties or their nutritional value data.

Mushrooms contain organic acids (Ribeiro et al. 2006; Barros et al. 2013); however, their relation to trace element accumulation in fruiting bodies has not yet been studied. In plants, the content of low-molecular-weight organic acids (LMWOAs) varies considerably among species and cultivars (biotic factors), and it is also influenced by local (abiotic) factors such as soil, climate, pollution, etc. (Nawirska-Olszańska et al. 2014). Extremely adverse growth conditions, such as high concentration of metals in soil, low nutrient contents, low/high humidity, acidification, or salinity, initiate a defense mechanism, which promotes survival under difficult environmental conditions. Efficient ways to reduce the toxicity of metals present in soil include both a range of extracellular strategies, which involve reducing metal uptake by immobilizing them in the soil matrix, and transport of metals to the aerial part of plants. However, when metals get into the cell, intracellular mechanisms are activated based on metal-ligand complexation, where phytochelatins, LMWOAs, are used for the compartmentation of complexes into the vacuole. LMWOAs, such as oxalic, citric, malonic, succinic, and/or tartaric acids exudated by plants (Dresler et al. 2014) or mushrooms (Ousmanova and Parker 2007), have been known to have a capacity to remove heavy metals from polluted soil. However, to date, studies evaluating possible relationships between LMWOAs in mushrooms and trace element concentrations are scarce.

The aim of the study was to compare the ability of $B$. badius fruiting bodies collected from two unpolluted and two polluted sites to (i) accumulate 53 elements and (ii) form selected LMWOAs, and finally, (iii) an evaluation of the possible relationship between elements and LMWOA content in mushrooms was made.

\section{Materials and methods}

\section{Experimental material}

Samples of $B$. badius fruiting bodies and underlying substrates (soils, flotation tailings) were collected between 20 September and 4 October 2015 from four sites located in central and southeastern Poland. Two of the sites were unpolluted areas of acidic sandy soils located in the Wielkopolska region (site 1 and site 2), while the other two sites were located in the Voivodeship of Lower Silesia (site 3 and site 4), where alkaline flotation tailings from copper production have been stored (Table 1). The used substrate (code 0103 81) was the wastes from the flotational enrichment of non-ferrous metal ore other than presented in 010380 in accordance with the Regulation of the Ministry of Economy (2015).

Fruiting bodies were collected from four, two, three, and two places within unpolluted site 1 , unpolluted site 2, polluted site 3 , and polluted site 4 , respectively. Five collected fruiting bodies were analyzed from each of polluted and unpolluted site. As $B$. badius is an ectomycorrhizal species living in association with trees, the selection of sites was related to the presence of the same tree species. All sampled B. badius grew in association with Pinus sylvestris L. Samples of each underlying soil/flotation tailing $(0.5 \mathrm{~kg})$ were collected from the same locations as the collected mushrooms. Both soils/ flotation tailings and mushroom fruiting bodies were transported immediately after collection to the laboratory for samples preparation and analysis.

\section{Determination of elements}

\section{Reagents}

All used reagents were of analytical purity. Deionized ultrapure water was produced in a Milli-Q device (Millipore, Saint Luis, USA). Concentrated nitric acid (Merck, Darmstadt, Germany) was used for the preparation of samples and reference materials. ICP commercial analytical standards (Romil, England) were used for inductively coupled plasma optical emission spectrometry (ICP-OES) analysis. The standard reference materials CRM S-1-loess soil, CRM NCSDC (73349) — bush branches and leaves, and CRM 2709-soil were used for analysis quality control.

\section{Procedure}

Mushroom fruiting bodies were dried at $50 \pm 2{ }^{\circ} \mathrm{C}$ for $96 \mathrm{~h}$ in an electric oven (SLW 53 STD, Pol-Eko, Wodzisław Śląski, Poland) and powdered in a laboratory Cutting Boll Mill PM 200 (Retsch GmbH, Haan, Germany). Accurately weighed $0.300 \pm 0.001 \mathrm{~g}$ of each dry sample was digested with concentrated nitric acid in closed Teflon containers in the microwave digestion system Mars 5 Xpress (CEM, Matthews, NC, USA). Samples were then filtered through a paper filter (Qualitative Filter Papers, Whatman, grade 595 4-7 $\mu \mathrm{m}$, UK) and diluted with water to a total volume of $15.0 \mathrm{~mL}$. Each of the samples was analyzed in triplicate from the start of weighing. For each series of analysis, the reagent blank was 
Table 1 Characteristics of sites where Boletus badius samples and underlying substrates were collected

\begin{tabular}{llc}
\hline Sample collection areas & GPS position & $\begin{array}{c}\text { Elevation } \\
\text { [m above sea level] }\end{array}$ \\
\hline Site 1 unpolluted (forest area, soil) & $52^{\circ} 44^{\prime} 50.84^{\prime \prime} \mathrm{N} 17^{\circ} 11^{\prime} 58.27^{\prime \prime} \mathrm{E}$ & 85 \\
Site 2 unpolluted (forest area, soil) & $52^{\circ} 42^{\prime} 02.17^{\prime \prime} \mathrm{N} 17^{\circ} 06^{\prime} 00.70^{\prime \prime} \mathrm{E}$ & 94 \\
Site 3 polluted (flotation tailing) & $51^{\circ} 12^{\prime} 34.40^{\prime \prime} \mathrm{N} 15^{\circ} 43^{\prime} 29.56^{\prime \prime} \mathrm{E}$ & 235 \\
Site 4 polluted (flotation tailing) & $51^{\circ} 12^{\prime} 38.96^{\prime \prime} \mathrm{N} 15^{\circ} 40^{\prime} 51.30^{\prime \prime} \mathrm{E}$ & 242 \\
\hline
\end{tabular}

analyzed. Soil/flotation tailing extraction by nitric acid was provided based on the scheme described above.

The $\mathrm{pH}$ determination was carried out for water extracts of solid samples with a direct electrochemical $\mathrm{pH}$ measurement obtained from a commercial $\mathrm{pH}$ meter. The redox potential determination was based on the measurement of the difference of potential between the platinum electrode and a standard hydrogen electrode (reference electrode). The electrochemical measurements of $\mathrm{pH}$ and redox potential including instrument calibrations were undertaken in accordance with ISO norms (ISO 10390 2005; ISO 11271 2002).

\section{Instruments}

The inductively coupled plasma optical emission spectrometer Agilent 5100 ICP-OES (Agilent, USA) was used for the determination of five major elements $(\mathrm{Ca}, \mathrm{K}, \mathrm{Mg}, \mathrm{Na}$, and $\mathrm{P})$ and 47 trace elements (Ag, Al, $\mathrm{As}, \mathrm{Au}, \mathrm{B}, \mathrm{Ba}, \mathrm{Bi}, \mathrm{Cd}, \mathrm{Ce}, \mathrm{Co}, \mathrm{Cr}$, $\mathrm{Cu}$, Dy, Er, Eu, Fe, Ga, Gd, Ge, Ho, In, Ir, La, Li, Lu, Mn, Mo, $\mathrm{Nd}, \mathrm{Ni}, \mathrm{Pb}, \mathrm{Pd}, \mathrm{Pr}, \mathrm{Pt}, \mathrm{Te}, \mathrm{Rh}, \mathrm{Ru}, \mathrm{Sb}, \mathrm{Sc}, \mathrm{Se}, \mathrm{Sm}, \mathrm{Sr}, \mathrm{Te}, \mathrm{Tl}$, $\mathrm{Tm}, \mathrm{Y}, \mathrm{Yb}$, and $\mathrm{Zn}$ ). A synchronous vertical dual view (SVDV) of the plasma was accomplished using dichroic spectral combiner (DSC) technology, which allows axial and radial view analysis simultaneously. Common conditions were applied: radio frequency $(\mathrm{RF})$ power $1.2 \mathrm{~kW}$, nebulizer gas flow $0.7 \mathrm{~L} \mathrm{~min}^{-1}$, auxiliary gas flow $1.0 \mathrm{~L} \mathrm{~min}^{-1}$, plasma gas flow 12.0 $\mathrm{L} \mathrm{min}^{-1}$, charge coupled device (CCD) temperature $-40{ }^{\circ} \mathrm{C}$, viewing height for radial plasma observation $8 \mathrm{~mm}$, accusation time $5 \mathrm{~s}$, three replicates.

Mercury concentration was measured with electrothermal atomic absorption spectrometry (ETAAS) and Zeeman background correction. A SpectrAA 280Z (Agilent Technologies, Australia) instrument equipped with pyrolytic graphite tubes and an $\mathrm{Hg}$ hollow cathode lamp (wavelength $253.7 \mathrm{~nm}$, slit $0.5 \mathrm{~nm}$, current $4 \mathrm{~mA}$ ) was used. The temperature program was optimized: $55 \mathrm{~s}$ of drying at $85-120^{\circ} \mathrm{C}, 8 \mathrm{~s}$ of ashing at $400{ }^{\circ} \mathrm{C}$, and atomization at $1800{ }^{\circ} \mathrm{C}$. As a chemical modifier, palladium solution $\left(1000 \mathrm{mg} \mathrm{L}^{-1}\right)$ was used in a volume of $10 \mu \mathrm{L}$ for $20 \mu \mathrm{L}$ of the sample. The limit of detection was found at the level of $0.01 \mathrm{mg} \mathrm{kg}^{-1}$, and uncertainty (measured as RSD) at a level of $5.0 \%$ was obtained. Traceability was determined by the standard reference material analysis (mushroom material CS-M-I (LGC Standards, Poland) certified value $0.174 \pm 0.018 \mathrm{mg} \mathrm{kg}^{-1}$, obtained value $0.16 \pm 0.03 \mathrm{mg} \mathrm{kg}^{-1}$, recovery $94 \%$ ).

\section{Analytical method validation}

The detection limits were determined as 3-sigma criteria and were at the level of $0.01 \mathrm{mg} \mathrm{kg}^{-1}$ dry weight (DW) for all elements determined. The uncertainty for complete analytical process (including sample preparation) was at the level of $20 \%$. Traceability was checked using the reference materials listed above. The recovery (80-120\%) was acceptable for all elements determined, as presented in Supplementary data (Table S1). No certified values of concentration were available for several elements (Ag, Au, Bi, Ga, Ge, Ho, In, Ir, Pd, Pr, Pt, $\mathrm{Re}, \mathrm{Rh}, \mathrm{Ru}, \mathrm{Tl}, \mathrm{Sm}, \mathrm{Tm}, \mathrm{Y}$, and $\mathrm{Yb}$ ), and determined contents in the samples are presented in Supplementary data (Table S2S4).

\section{Analysis of low-molecular-weight organic acids}

\section{Reagents}

The LMWOA standards (acetic, citric, formic, fumaric, lactic, maleic, malic, malonic, oxalic, and succinic acids) were purchased from Supelco with a certified standard grade. Potassium dihydrogen phosphate $\left(\mathrm{KH}_{2} \mathrm{PO}_{4}\right)$ and concentrated phosphoric acid $\left(\mathrm{H}_{3} \mathrm{PO}_{4}\right)$ of analytical grade (Sigma) were used for $\mathrm{pH}$ adjustment of the mobile phase. Aqueous solution of the mobile phase was prepared from Milli-Q water (Millipore, Saint Luis, USA). Methanol was of HPLC grade, purchased from Sigma.

\section{Procedure}

Dried (at $50 \pm 2{ }^{\circ} \mathrm{C}$ for $96 \mathrm{~h}$ ) and powdered mushroom samples $(5.0 \mathrm{~g})$ were suspended in $20 \mathrm{~mL}$ deionized water (MilliQ water, Millipore, Saint Luis, USA) and subjected to ultrasound action $(400 \mathrm{~W}, 30 \mathrm{~min}$, ambient temperature) using a $1500 \mathrm{~W}$ high-intensity ultrasonic processor (Sonorex Super RK 100H, Bandelin Electronic, Germany). The suspension was centrifuged at $3200 \times \mathrm{g}$ for $15 \mathrm{~min}$ (Universal $320 \mathrm{R}$, Hettich, Tuttlingen, Germany), and the supernatant was filtered through a $0.45-\mu \mathrm{m}$ cellulose membrane (Millipore) prior 
to analysis by reversed-phase column liquid chromatography (RPLC).

\section{Instruments}

RPLC was used for the separation and quantification of ten organic acids (acetic, citric, formic, fumaric, lactic, maleic, malic, malonic, oxalic, and succinic) in B. badius samples. RPLC analyses were conducted with a Waters Alliance 2695 Chromatograph coupled with a Waters 2996 Photodiode Array Detector (Waters Corp., Milford, MA, USA). Separation was performed on a Waters Atlantis C18 column $(250 \times 4.6 \mathrm{~mm})$ with $5 \mu \mathrm{m}$ particle size. RPLC conditions were as follows: mobile phase, $25 \mathrm{mM} \mathrm{KH}_{2} \mathrm{PO}_{4}$ adjusted to pH 2.5 with concentrated phosphoric acid and methanol (95:5, $v / v$ ) flow rate $0.8 \mathrm{~mL} \mathrm{~min}^{-1}$; UV detection wavelength $220 \mathrm{~nm}$; at an ambient temperature of $25 \pm 2{ }^{\circ} \mathrm{C}$; and injection volume $10 \mu \mathrm{L}$. For the analysis of mushroom samples, gradient elution was used in every fifth sample to obtain $95 \%$ methanol in 15 min to fully flush the column of hydrophobic compounds from previous injections (Cawthray 2003).

\section{Analytical method validation}

Analyzed organic acids were identified based on the retention time $\left(R_{\mathrm{t}}\right)$ of original standards and their characteristic UV spectra and on the basis of external standard methods. For every analyzed organic acid, the calibration line equation and calibration coefficient, the limits of detection (LODs), and limits of quantification (LOQs) were calculated. LODs were calculated in a concentration range of the standards: 100-2000 $\mathrm{g} \mathrm{mL}^{-1}$ for oxalic, malic, malonic, lactic, citric, and succinic; $50-500 \mu \mathrm{g} \mathrm{mL}^{-1}$ for acetic; $10-100 \mu \mathrm{g} \mathrm{mL}^{-1}$ for formic; $0.05-0.50 \mu \mathrm{g} \mathrm{mL} \mathrm{m}^{-1}$ for fumaric; and $0.01-$ $0.10 \mu \mathrm{g} \mathrm{mL}^{-1}$ for maleic, with an injection volume of $10 \mu \mathrm{L}$ (Table S5).

\section{Statistical analysis}

Statistical analysis was done using STATISTICA 10 and consisted of ANOVA followed by the post hoc Tukey's test. The identical letters in rows, jointly for elements analyzed in samples (mushrooms, flotation tailings/soils) collected from both unpolluted and polluted areas, represent no differences at the significance level $\alpha=0.05$. Additionally, to determine correlation between element content in soil to their content in fruiting bodies $\left(r_{1}\right)$ and also between the element and total LMWOA contents in fruiting bodies $\left(r_{2}\right)$, the Pearson correlation coefficient $(r)$ values were calculated.

\section{Results and discussion}

\section{Concentration of elements in soils/flotation tailings}

Data on elements in tested soils and flotation tailings are presented in Table 2 and in Supplementary data (Table S2) for

Table 2 Content of elements [mg kg-1 DW] in tested soils/flotation tailings with $\mathrm{pH}$ and Eh values

\begin{tabular}{|c|c|c|c|c|}
\hline \multirow[t]{2}{*}{ Element } & \multicolumn{2}{|c|}{ Unpolluted area } & \multicolumn{2}{|l|}{ Polluted area } \\
\hline & Site 1 & Site 2 & Site 3 & Site 4 \\
\hline $\mathrm{Ca}$ & $3896^{\mathrm{c}} \pm 148$ & $4228^{c} \pm 210$ & $24652^{\mathrm{a}} \pm 3389$ & $10976^{\mathrm{b}} \pm 847$ \\
\hline K & $6722^{\mathrm{a}} \pm 345$ & $7268^{a} \pm 253$ & $3621^{b} \pm 265$ & $2054^{\mathrm{c}} \pm 158$ \\
\hline $\mathrm{Mg}$ & $271^{\mathrm{c}} \pm 22$ & $309^{c} \pm 13$ & $4762^{\mathrm{a}} \pm 303$ & $2326^{\mathrm{b}} \pm 120$ \\
\hline $\mathrm{Na}$ & $328^{a} \pm 61$ & $385^{\mathrm{a}} \pm 15$ & $305^{\mathrm{a}} \pm 8$ & $128^{\mathrm{b}} \pm 15$ \\
\hline $\mathrm{P}$ & $4236^{\mathrm{a}} \pm 119$ & $4588^{\mathrm{a}} \pm 161$ & $3625^{\mathrm{b}} \pm 105$ & $3398^{b} \pm 187$ \\
\hline $\mathrm{Al}$ & $497^{\mathrm{d}} \pm 32$ & $892^{c} \pm 37$ & $4821^{\mathrm{a}} \pm 167$ & $2965^{b} \pm 229$ \\
\hline As & $0.21^{\mathrm{c}} \pm 0.04$ & $0.43^{\mathrm{c}} \pm 0.07$ & $21.4^{\mathrm{a}} \pm 2.9$ & $8.80^{\mathrm{b}} \pm 0.70$ \\
\hline B & $0.98^{\mathrm{c}} \pm 0.18$ & $0.65^{\mathrm{c}} \pm 0.10$ & $54.6^{\mathrm{a}} \pm 7.5$ & $10.4^{\mathrm{b}} \pm 0.8$ \\
\hline $\mathrm{Ba}$ & $16.0^{\mathrm{c}} \pm 3.0$ & $14.0^{c} \pm 2.0$ & $141^{\mathrm{a}} \pm 19$ & $37.0^{\mathrm{b}} \pm 3.0$ \\
\hline $\mathrm{Cd}$ & $0.24^{\mathrm{c}} \pm 0.04$ & $0.31^{\mathrm{c}} \pm 0.05$ & $0.51^{b} \pm 0.07$ & $1.33^{\mathrm{a}} \pm 0.10$ \\
\hline $\mathrm{Ce}$ & $3.76^{\mathrm{c}} \pm 0.70$ & $2.08^{c} \pm 0.33$ & $18.9^{\mathrm{a}} \pm 2.60$ & $8.87^{\mathrm{b}} \pm 0.68$ \\
\hline Co & $0.65^{\mathrm{c}} \pm 0.12$ & $0.48^{\mathrm{c}} \pm 0.08$ & $34.6^{\mathrm{a}} \pm 4.8$ & $7.70^{b} \pm 0.59$ \\
\hline $\mathrm{Cr}$ & $1.76^{\mathrm{c}} \pm 0.33$ & $1.61^{\mathrm{c}} \pm 0.26$ & $14.9^{\mathrm{a}} \pm 2.0$ & $7.90^{\mathrm{b}} \pm 0.61$ \\
\hline $\mathrm{Cu}$ & $1.55^{\mathrm{c}} \pm 0.29$ & $1.31^{\mathrm{c}} \pm 0.21$ & $912^{\mathrm{b}} \pm 125$ & $2143^{\mathrm{a}} \pm 142$ \\
\hline Dy & $0.11^{\mathrm{b}} \pm 0.02$ & $0.14^{\mathrm{b}} \pm 0.02$ & $1.31^{\mathrm{a}} \pm 0.18$ & $0.09^{\mathrm{b}} \pm 0.01$ \\
\hline $\mathrm{Er}$ & $1.64^{\mathrm{c}} \pm 0.31$ & $2.55^{\mathrm{c}} \pm 0.41$ & $25.3^{\mathrm{a}} \pm 3.5$ & $10.9^{\mathrm{b}} \pm 0.8$ \\
\hline $\mathrm{Eu}$ & $0.05^{\mathrm{c}} \pm 0.01$ & $0.03^{\mathrm{c}} \pm 0.01$ & $0.37^{\mathrm{a}} \pm 0.05$ & $0.15^{\mathrm{b}} \pm 0.01$ \\
\hline $\mathrm{Fe}$ & $1313^{\mathrm{c}} \pm 86$ & $1569^{c} \pm 39$ & $6599^{\mathrm{a}} \pm 529$ & $3820^{b} \pm 199$ \\
\hline Gd & $0.06^{\mathrm{c}} \pm 0.01$ & $0.04^{\mathrm{c}} \pm 0.01$ & $3.89^{\mathrm{a}} \pm 0.53$ & $1.21^{\mathrm{b}} \pm 0.09$ \\
\hline $\mathrm{Hg}$ & $0.11^{\mathrm{b}} \pm 0.02$ & $0.19^{b} \pm 0.03$ & $0.34^{\mathrm{a}} \pm 0.05$ & $0.43^{\mathrm{a}} \pm 0.03$ \\
\hline $\mathrm{La}$ & $0.41^{\mathrm{c}} \pm 0.08$ & $0.18^{\mathrm{c}} \pm 0.03$ & $6.90^{\mathrm{a}} \pm 0.95$ & $4.50^{\mathrm{b}} \pm 0.40$ \\
\hline $\mathrm{Li}$ & $0.42^{\mathrm{c}} \pm 0.08$ & $0.61^{\mathrm{c}} \pm 0.10$ & $21.0^{\mathrm{a}} \pm 2.9$ & $10.7^{\mathrm{b}} \pm 0.8$ \\
\hline $\mathrm{Lu}$ & $0.04^{\mathrm{b}} \pm 0.01$ & $0.03^{\mathrm{b}} \pm 0.01$ & $0.29^{\mathrm{a}} \pm 0.04$ & $0.08^{\mathrm{b}} \pm 0.01$ \\
\hline $\mathrm{Mn}$ & $23.0^{\mathrm{c}} \pm 4.0$ & $25.0^{\mathrm{c}} \pm 4.0$ & $1502^{\mathrm{a}} \pm 76$ & $659^{\mathrm{b}} \pm 51$ \\
\hline Mo & $0.32^{\mathrm{b}} \pm 0.06$ & $0.28^{\mathrm{b}} \pm 0.04$ & $12.9^{\mathrm{a}} \pm 1.8$ & $17.1^{\mathrm{a}} \pm 1.3$ \\
\hline $\mathrm{Nd}$ & $5.88^{\mathrm{b}} \pm 1.10$ & $6.79^{\mathrm{b}} \pm 1.08$ & $95.0^{\mathrm{a}} \pm 13.0$ & $79.0^{\mathrm{a}} \pm 6.0$ \\
\hline $\mathrm{Ni}$ & $0.88^{\mathrm{C}} \pm 0.16$ & $1.01^{\mathrm{c}} \pm 0.16$ & $25.4^{\mathrm{a}} \pm 3.5$ & $8.4^{\mathrm{b}} \pm 0.7$ \\
\hline $\mathrm{Pb}$ & $5.23^{\mathrm{c}} \pm 0.98$ & $3.86^{\mathrm{c}} \pm 0.61$ & $476^{\mathrm{a}} \pm 15$ & $79.0^{\mathrm{b}} \pm 6.1$ \\
\hline $\mathrm{Sb}$ & $0.11^{\mathrm{c}} \pm 0.02$ & $0.14^{\mathrm{c}} \pm 0.02$ & $1.14^{\mathrm{a}} \pm 0.16$ & $0.38^{\mathrm{b}} \pm 0.03$ \\
\hline $\mathrm{Sc}$ & $0.15^{\mathrm{c}} \pm 0.03$ & $0.09^{c} \pm 0.01$ & $2.64^{\mathrm{a}} \pm 0.36$ & $1.41^{\mathrm{b}} \pm 0.11$ \\
\hline $\mathrm{Se}$ & $0.03^{\mathrm{c}} \pm 0.01$ & $0.02^{\mathrm{c}} \pm 0.01$ & $0.21^{\mathrm{b}} \pm 0.03$ & $0.65^{\mathrm{a}} \pm 0.05$ \\
\hline $\mathrm{Sr}$ & $3.02^{\mathrm{c}} \pm 056$ & $5.00^{c} \pm 0.79$ & $517^{\mathrm{a}} \pm 18$ & $206^{\mathrm{b}} \pm 16$ \\
\hline $\mathrm{Te}$ & $0.26^{\mathrm{b}} \pm 0.05$ & $0.17^{\mathrm{b}} \pm 0.03$ & $1.67^{\mathrm{a}} \pm 0.23$ & $0.37^{b} \pm 0.03$ \\
\hline $\mathrm{Zn}$ & $21.0^{\mathrm{c}} \pm 2.0$ & $16.0^{\mathrm{c}} \pm 1.0$ & $47.0^{\mathrm{a}} \pm 2.0$ & $40.0^{\mathrm{b}} \pm 3.0$ \\
\hline $\mathrm{pH}$ & $5.03^{\mathrm{c}} \pm 0.10$ & $4.78^{\mathrm{c}} \pm 0.17$ & $7.99^{b} \pm 0.08$ & $8.17^{\mathrm{a}} \pm 0.12$ \\
\hline Eh & $551^{\mathrm{a}} \pm 19$ & $516^{\mathrm{b}} \pm 25$ & $386^{\mathrm{c}} \pm 43$ & $361^{\mathrm{c}} \pm 32$ \\
\hline
\end{tabular}

Mean values $(n=5) \pm$ standard deviations; identical superscripts denote significant $(p<0.05)$ difference between mean values in lines according to Tukey's HSD test (ANOVA) for soils 
elements with data on the informative value of their concentration. The concentration of most elements (excluding elements presented in Supplementary data) in both soils (sites 1 and 2) was similar, with the exception of Al, which was significantly lower than its level in flotation tailings.

No significant differences in the concentration of $\mathrm{Mo}, \mathrm{Nd}$, and $\mathrm{P}$ in flotation tailings collected from sites 3 and 4 were observed. The concentration of $\mathrm{Cd}, \mathrm{Cu}$, and $\mathrm{Se}$ in flotation tailings collected from site 4 was higher than from site 3 , while the inverse situation was stated for the rest of the elements. It can be assumed that the concentration of the latter elements in $B$. badius fruiting bodies growing on flotation tailings at site 3 should be significantly higher than in bodies from site 4 . It is worth noting that $\mathrm{K}$ and $\mathrm{P}$ concentration was significantly higher in soils than in flotation tailings. Moreover, no significant differences in $\mathrm{Lu}, \mathrm{Na}$, and Te concentration were observed between soils and tailings but irregularly among sites within both the underlying substrates.

\section{Content of elements in $B$. badius fruiting bodies}

Data on the content of 53 elements in fruiting bodies of B. badius are presented in Table 3 and in Supplementary data (Table S3) for elements with information on the (informative) value of their concentration.

Based on the results of statistical testing, four groups of elements (with the exception of elements presented in Supplementary data) were indicated as regards their content in mushroom bodies from unpolluted and polluted areas. The largest group I consists of 19 elements with significantly higher content in fruiting bodies from polluted areas than from unpolluted ones. This group comprised Al, As, B, Ca, Ce, Co, Dy, Er, Eu, Hg, Lu, Mg, Mo, Nd, Pb, Sb, Se, Sr, and Te. An inverse situation was observed in five elements $(\mathrm{Ba}, \mathrm{Li}, \mathrm{Mn}$, $\mathrm{Na}$, and P) forming group II. Kojta et al. (2012) reported the same observation for $\mathrm{Na}$ and $\mathrm{P}$ which would suggest that these elements accumulate in a different way. For the five elements $(\mathrm{Cd}, \mathrm{Cr}, \mathrm{Cu}, \mathrm{Fe}$, and $\mathrm{K})$ forming group III, no significant differences were stated in the contents of B. badius bodies collected from unpolluted and polluted areas. Group IV consists of the remaining five elements ( $\mathrm{Gd}, \mathrm{La}, \mathrm{Ni}, \mathrm{Sc}$, and $\mathrm{Zn}$ ), the contents of which vary irregularly among sites from unpolluted and polluted areas. Data of Table 3 suggest that there is a greater accumulation of most of the determined elements in fruiting bodies from polluted rather than from unpolluted areas, although five elements forming group II were accumulated at greater levels in fruiting bodies growing in unpolluted areas. Such results together with observations for the groups III and IV suggest that the content of elements in underlying substrate (soil/flotation tailing) is not the only factor affecting the rate of accumulation in fruiting bodies.

Due to differing levels of elements in the underlying substrates, there arises a question regarding the possible
Table 3 Content of elements [ $\left.\mathrm{mg} \mathrm{kg}^{-1} \mathrm{DW}\right]$ in Boletus badius fruit bodies collected from unpolluted and polluted areas

\begin{tabular}{|c|c|c|c|c|}
\hline \multirow[t]{2}{*}{ Element } & \multicolumn{2}{|c|}{ Unpolluted area } & \multicolumn{2}{|l|}{ Polluted area } \\
\hline & Site 1 & Site 2 & Site 3 & Site 4 \\
\hline $\mathrm{Ca}$ & $24^{\mathrm{c}} \pm 4$ & $33^{c} \pm 9$ & $2706^{\mathrm{a}} \pm 166$ & $2322^{\mathrm{b}} \pm 126$ \\
\hline K & $18932^{\mathrm{a}} \pm 640$ & $17584^{a} \pm 1178$ & $1731^{\mathrm{a}} \pm 456$ & $1968^{\mathrm{a}} \pm 1151$ \\
\hline $\mathrm{Mg}$ & $111^{\mathrm{c}} \pm 18$ & $82^{\mathrm{c}} \pm 14$ & $611^{\mathrm{a}} \pm 23$ & $503^{b} \pm 26$ \\
\hline $\mathrm{Na}$ & $273^{\mathrm{a}} \pm 28$ & $226^{\mathrm{a}} \pm 21$ & $148^{b} \pm 5$ & $121^{b} \pm 20$ \\
\hline $\mathrm{P}$ & $4377^{a} \pm 220$ & $4401^{\mathrm{a}} \pm 299$ & $3893^{\mathrm{b}} \pm 231$ & $3602^{b} \pm 318$ \\
\hline $\mathrm{Al}$ & $18^{\mathrm{b}} \pm 3$ & $14^{\mathrm{b}} \pm 4$ & $37^{\mathrm{a}} \pm 3$ & $39^{\mathrm{a}} \pm 2$ \\
\hline As & $0.22^{\mathrm{b}} \pm 0.04$ & $0.16^{\mathrm{b}} \pm 0.04$ & $0.49^{\mathrm{a}} \pm 0.09$ & $0.41^{\mathrm{a}} \pm 0.05$ \\
\hline B & $0.28^{\mathrm{b}} \pm 0.04$ & $0.19^{b} \pm 0.05$ & $2.59^{\mathrm{a}} \pm 0.46$ & $3.16^{\mathrm{a}} \pm 0.44$ \\
\hline $\mathrm{Ba}$ & $9.4^{\mathrm{a}} \pm 1.5$ & $7.9^{\mathrm{a}} \pm 2.0$ & $0.60^{\mathrm{b}} \pm 0.10$ & $0.80^{\mathrm{b}} \pm 0.10$ \\
\hline $\mathrm{Cd}$ & $0.24^{\mathrm{a}} \pm 0.04$ & $0.19^{\mathrm{a}} \pm 0.05$ & $0.30^{\mathrm{a}} \pm 0.06$ & $0.26^{\mathrm{a}} \pm 0.04$ \\
\hline $\mathrm{Ce}$ & $0.11^{\mathrm{b}} \pm 0.02$ & $0.11^{\mathrm{b}} \pm 0.03$ & $1.95^{\mathrm{a}} \pm 0.37$ & $1.64^{\mathrm{a}} \pm 0.23$ \\
\hline Co & $0.03^{b} \pm 0.02$ & $0.04^{\mathrm{b}} \pm 0.01$ & $0.19^{\mathrm{a}} \pm 0.04$ & $0.15^{\mathrm{a}} \pm 0.02$ \\
\hline $\mathrm{Cr}$ & $0.14^{\mathrm{a}} \pm 0.02$ & $0.18^{\mathrm{a}} \pm 0.05$ & $0.18^{\mathrm{a}} \pm 0.03$ & $0.13^{\mathrm{a}} \pm 0.02$ \\
\hline $\mathrm{Cu}$ & $14^{\mathrm{a}} \pm 2$ & $17^{\mathrm{a}} \pm 4$ & $13^{\mathrm{a}} \pm 2$ & $9^{a} \pm 1$ \\
\hline Dy & $0.03^{\mathrm{b}} \pm 0.01$ & $0.04^{\mathrm{b}} \pm 0.01$ & $0.07^{\mathrm{a}} \pm 0.01$ & $0.09^{\mathrm{a}} \pm 0.01$ \\
\hline $\mathrm{Er}$ & $0.03^{\mathrm{b}} \pm 0.01$ & $0.04^{\mathrm{b}} \pm 0.01$ & $0.49^{\mathrm{a}} \pm 0.09$ & $0.55^{\mathrm{a}} \pm 0.08$ \\
\hline $\mathrm{Eu}$ & $0.01^{\mathrm{b}} \pm 0.01$ & $0.01^{\mathrm{b}} \pm 0.01$ & $0.02^{\mathrm{a}} \pm 0.01$ & $0.02^{\mathrm{a}} \pm 0.01$ \\
\hline $\mathrm{Fe}$ & $24^{\mathrm{a}} \pm 4$ & $29^{a} \pm 7$ & $28^{\mathrm{a}} \pm 5$ & $35^{\mathrm{a}} \pm 2$ \\
\hline Gd & $0.05^{\mathrm{b}} \pm 0.01$ & $0.02^{\mathrm{c}} \pm 0.01$ & $0.05^{\mathrm{b}} \pm 0.01$ & $0.09^{\mathrm{a}} \pm 0.01$ \\
\hline $\mathrm{Hg}$ & $0.32^{\mathrm{b}} \pm 0.05$ & $0.21^{\mathrm{b}} \pm 0.05$ & $0.89^{\mathrm{a}} \pm 0.17$ & $0.96^{\mathrm{a}} \pm 0.13$ \\
\hline $\mathrm{La}$ & $0.09^{\mathrm{ab}} \pm 0.01$ & $0.11^{\mathrm{a}} \pm 0.03$ & $0.08^{\mathrm{ab}} \pm 0.02$ & $0.06^{\mathrm{b}} \pm 0.01$ \\
\hline $\mathrm{Li}$ & $0.06^{\mathrm{a}} \pm 0.01$ & $0.08^{\mathrm{a}} \pm 0.01$ & $0.03^{\mathrm{b}} \pm 0.01$ & $0.04^{\mathrm{b}} \pm 0.01$ \\
\hline $\mathrm{Lu}$ & $0.01^{\mathrm{b}} \pm 0.01$ & $0.01^{\mathrm{b}} \pm 0.01$ & $0.02^{\mathrm{a}} \pm 0.01$ & $0.02^{\mathrm{a}} \pm 0.01$ \\
\hline $\mathrm{Mn}$ & $11.3^{\mathrm{a}} \pm 1.8$ & $14.3^{\mathrm{a}} \pm 3.7$ & $1.80^{\mathrm{b}} \pm 0.30$ & $1.40^{\mathrm{b}} \pm 0.20$ \\
\hline Mo & $0.04^{\mathrm{b}} \pm 0.01$ & $0.03^{\mathrm{b}} \pm 0.01$ & $0.15^{\mathrm{a}} \pm 0.03$ & $0.11^{\mathrm{a}} \pm 0.02$ \\
\hline $\mathrm{Nd}$ & $0.05^{\mathrm{b}} \pm 0.01$ & $0.03^{\mathrm{b}} \pm 0.01$ & $9.38^{\mathrm{a}} \pm 0.68$ & $7.71^{\mathrm{a}} \pm 1.08$ \\
\hline $\mathrm{Ni}$ & $0.37^{\mathrm{a}} \pm 0.06$ & $0.29^{\mathrm{ab}} \pm 0.07$ & $0.26^{\mathrm{ab}} \pm 0.05$ & $0.19^{b} \pm 0.03$ \\
\hline $\mathrm{Pb}$ & $0.11^{\mathrm{c}} \pm 0.02$ & $0.17^{\mathrm{b}} \pm 0.04$ & $0.59^{\mathrm{a}} \pm 0.11$ & $0.64^{\mathrm{a}} \pm 0.09$ \\
\hline $\mathrm{Sb}$ & $0.03^{\mathrm{b}} \pm 0.01$ & $0.02^{\mathrm{b}} \pm 0.01$ & $0.31^{\mathrm{a}} \pm 0.06$ & $0.24^{\mathrm{a}} \pm 0.03$ \\
\hline $\mathrm{Sc}$ & $0.03^{\mathrm{c}} \pm 0.01$ & $0.04^{\mathrm{bc}} \pm 0.01$ & $0.07^{\mathrm{a}} \pm 0.01$ & $0.06^{\mathrm{ab}} \pm 0.01$ \\
\hline $\mathrm{Se}$ & $0.02^{\mathrm{b}} \pm 0.01$ & $0.01^{\mathrm{b}} \pm 0.01$ & $2.78^{a} \pm 0.53$ & $3.54^{\mathrm{a}} \pm 0.50$ \\
\hline $\mathrm{Sr}$ & $0.19^{\mathrm{b}} \pm 0.03$ & $0.15^{\mathrm{b}} \pm 0.04$ & $2.65^{\mathrm{a}} \pm 0.51$ & $1.94^{\mathrm{a}} \pm 0.27$ \\
\hline $\mathrm{Te}$ & $0.02^{\mathrm{b}} \pm 0.01$ & $0.01^{\mathrm{b}} \pm 0.01$ & $0.33^{\mathrm{a}} \pm 0.06$ & $0.26^{\mathrm{a}} \pm 0.04$ \\
\hline $\mathrm{Zn}$ & $72^{b} \pm 4$ & $88^{\mathrm{ab}} \pm 13$ & $109^{\mathrm{ab}} \pm 12$ & $86^{\mathrm{a}} \pm 6$ \\
\hline
\end{tabular}

Mean values $(n=5) \pm$ standard deviations; identical superscripts denote significant $(p<0.05)$ difference between mean values in lines according to Tukey's HSD test (ANOVA) for whole fruit bodies

correlation between element contents in soil/flotation tailings and their content in fruiting bodies $\left(r_{1}\right)$. Such a positive significant correlation was observed for 19 elements (Al, As, Ca, $\mathrm{Ce}, \mathrm{Co}, \mathrm{Er}, \mathrm{Eu}, \mathrm{Hg}, \mathrm{Lu}, \mathrm{Mg}, \mathrm{Mo}, \mathrm{Nd}, \mathrm{Pb}, \mathrm{Sb}, \mathrm{Sc}, \mathrm{Se}, \mathrm{Sr}, \mathrm{Te}$, and $\mathrm{Zn}$ ), collated in Table 4. Negative significant correlation was determined for $\mathrm{Ba}(-0.6792), \mathrm{Cu}(-0.7050)$, and $\mathrm{Mn}$ $(-0.8046)$. It is known that element accumulation in fruiting bodies does not simply depend on element content in 
Table 4 Pearson correlation coefficients $(r)$ for particular elements calculated between element content in underlying substrates to their content in Boletus badius fruit bodies $\left(r_{1}\right)$ and between element content and total low-molecular-weight organic acids content in fruit bodies $\left(r_{2}\right)$

\begin{tabular}{|c|c|c|c|c|c|}
\hline Element & $r_{1}$ & $r_{2}$ & Element & $r_{1}$ & $r_{2}$ \\
\hline $\mathrm{Ca}$ & $0.8602 *$ & $0.9726^{*}$ & $\mathrm{Fe}$ & 0.2059 & 0.3994 \\
\hline $\mathrm{K}$ & -0.3117 & 0.0711 & Gd & 0.2225 & 0.6798 \\
\hline $\mathrm{Mg}$ & $0.9439 *$ & $0.9843 *$ & $\mathrm{Hg}$ & $0.8589 *$ & $0.9618 *$ \\
\hline $\mathrm{Na}$ & -0.5225 & $-0.8217 *$ & $\mathrm{La}$ & -0.5404 & $-0.8179 *$ \\
\hline $\mathrm{P}$ & 0.5389 & $-0.5917 *$ & $\mathrm{Li}$ & -0.4578 & -0.2685 \\
\hline $\mathrm{Al}$ & $0.8848^{*}$ & $0.9754 *$ & $\mathrm{Lu}$ & $0.6216^{*}$ & $0.9664 *$ \\
\hline As & $0.8835^{*}$ & $0.9820 *$ & $\mathrm{Mn}$ & $-0.8046^{*}$ & $-0.9780 *$ \\
\hline B & 0.5680 & $0.9255^{*}$ & Mo & $0.8414^{*}$ & $0.9840 *$ \\
\hline $\mathrm{Ba}$ & $-0.6792 *$ & $-0.9250 *$ & $\mathrm{Nd}$ & $0.9847^{*}$ & $0.9752 *$ \\
\hline $\mathrm{Cd}$ & 0.2727 & $0.9487^{*}$ & $\mathrm{Ni}$ & -0.3522 & $-0.6152 *$ \\
\hline $\mathrm{Ce}$ & $0.8571^{*}$ & $0.9740 *$ & $\mathrm{~Pb}$ & $0.6260 *$ & $0.9180 *$ \\
\hline Co & $0.8047^{*}$ & $0.9654 *$ & $\mathrm{Sb}$ & $0.8314 *$ & $0.9825 *$ \\
\hline $\mathrm{Cr}$ & 0.1475 & -0.0996 & $\mathrm{Sc}$ & $0.8290 *$ & $0.9134 *$ \\
\hline $\mathrm{Cu}$ & $-0.7050^{*}$ & $-0.7903 *$ & $\mathrm{Se}$ & $0.8719 *$ & $0.9154 *$ \\
\hline Dy & 0.2429 & $0.8234 *$ & $\mathrm{Sr}$ & $0.9308 *$ & $0.9778 *$ \\
\hline $\mathrm{Er}$ & $0.7623^{*}$ & $0.9351 *$ & $\mathrm{Te}$ & $0.7428 *$ & $0.9816^{*}$ \\
\hline $\mathrm{Eu}$ & $0.8218^{*}$ & 0.7017 & $\mathrm{Zn}$ & $0.6495 *$ & 0.6534 \\
\hline
\end{tabular}

* Significant at $p<0.05$

substrate. Numerous papers have pointed to the significant role of environmental factors related with soil composition and its traits, although these factors are not clearly elucidated (Borovička and Řanda 2007; Campos and Tejera 2011; Falandysz and Bielawski 2007; Falandysz and Borovička 2013). A decrease of $\mathrm{pH}$ level is generally associated with increasing bioavailability of numerous elements, enabling their higher accumulation in plants (Blake and Goulding 2002; Tyler and Olsson 2001). Unfortunately, such relationships have not yet been defined for mushrooms.

\section{Profile of LMWOAs in mushroom}

Nine of the ten studied organic acids were determined by RPLC analysis. Maleic acid content was below LOD. Chromatograms of LMWOAs in mushrooms collected from unpolluted and polluted areas are shown in Fig. 1. The standards of analyzed LMWOAs are presented in Fig. 1a. The main peaks in Fig. 1b (unpolluted area) belonged to lactic acid and succinic acid, while in Fig. 1c (polluted area), next to them, a markedly elevated content of citric acid can be seen. No significant differences between the areas were observed in the contents of the remaining six organic acids (Table 5).

To the best of our knowledge, information on organic acid content and composition in $B$. badius fruiting bodies has been lacking to date. Fragmentary data for related species of the genus Boletus are available (Barros et al. 2013; Fernandes et al. 2014;
Leal et al. 2013; Ribeiro et al. 2008). Nevertheless, they deal particularly with citric, malic, and oxalic acids, whereas for several of the other acids collated in Table 5, there is little information. Generally, the reported contents vary widely and are higher (except for succinic acid) than the levels of Table 5.

The average content $(n=5)$ of lactic acid in fruiting bodies from the unpolluted sites 1 and 2 was $7.17 \pm 0.61$ and $9.60 \pm 1.53 \mathrm{mg} \mathrm{g}^{-1} \mathrm{DW}$, respectively (Table 5), while respective contents of succinic acid were $8.88 \pm 0.33$ and $5.30 \pm 0.38 \mathrm{mg} \mathrm{g}^{-1}$ DW. In the polluted sites 3 and 4, contents of lactic acid increased to $11.2 \pm 1.7$ and $14.8 \pm 2.0 \mathrm{mg} \mathrm{g}^{-1} \mathrm{DW}$, while those of succinic acid decreased to $4.23 \pm 0.61$ and $2.89 \pm 0.67 \mathrm{mg} \mathrm{g}^{-1}$ DW as compared the sites 1 and 2. Further, the content of citric acid in fruiting bodies from the polluted sites increased about tenfold when compared to the level from the unpolluted sites. Such a considerable increase may have an essential influence on the inherent ability to accumulate an excess of essential metals and non-essential metal ions as well (Böke et al. 2015). Biosynthesis of citric acid, an intermediate in the tricarboxylic acid cycle, can occur by way of glyoxylate oxidation (Gadd 1999). Citric acid may thus play an important role in metal homeostasis (Böke et al. 2015; Gadd 1999; LópezBucio et al. 2000) and with its metal complex-forming abilities provide essential metals and anionic nutrients for $B$. badius. Therefore, mushrooms may have an ecological advantage and be able to grow fairly well under different environmental conditions, e.g., metal contamination (Zeppa et al. 2012) or at very low pH values (Karaffa et al. 2001). However, as in the case of plants (Ghnaya et al. 2013; Magdziak et al. 2013), the composition and content of organic acids in fruiting bodies may depend on both mushroom species and environmental conditions.

\section{Relationship of element content and LMWOA profile}

An analysis of the relationship between element contents and total content of LMWOAs in mushrooms as a Pearson correlation coefficient $\left(r_{2}\right)$ are collated in Table 4 and in Supplementary data (Table S4) for elements with (informative) information on the value of their concentration.

A positive significant correlation was observed for 20 elements, namely Al, As, B, Ca, Cd, Ce, Co, Dy, Er, Hg, Lu, Mg, $\mathrm{Mo}, \mathrm{Nd}, \mathrm{Pb}, \mathrm{Sb}, \mathrm{Sc}, \mathrm{Se}, \mathrm{Sr}$, and Te, while a negative significant correlation was found for 7 elements $(\mathrm{Ba}, \mathrm{Cu}, \mathrm{La}, \mathrm{Mn}$, $\mathrm{Na}, \mathrm{Ni}$, and $\mathrm{P}$ ). A high proportion of positive correlation seems to confirm the important role of LMWOAs in element accumulation known in plants (Drzewiecka et al. 2014; Kutrowska and Szelag 2014; Goliński et al. 2015). Pearson correlation coefficients $(r)$ between the individual organic acid and element contents were also estimated (Table 6). According to the obtained results, a highly positive correlation ( $r=0.900)$ with some elements (Al, As, B, Ca, Ce, Co, Er, Hg, $\mathrm{Lu}, \mathrm{Mg}, \mathrm{Mo}, \mathrm{Na}, \mathrm{Nd}, \mathrm{Pb}, \mathrm{Sb}, \mathrm{Sc}, \mathrm{Se}, \mathrm{Sr}$, and $\mathrm{Te}$ ) is especially exhibited by citric acid and oxalic acid to $\mathrm{Al}, \mathrm{B}, \mathrm{Ce}, \mathrm{Er}, \mathrm{Nd}$, 
Fig. 1 Chromatograms of lowmolecular-weight organic acids of standards (a) and in mushrooms collected from unpolluted (b) and polluted (c) areas. Peaks: oxalic acid (1), formic acid (2), malic acid (3), malonic acid (4), lactic acid (5), acetic acid (6), maleic acid (7), citric acid (8), fumaric acid (9), and succinic acid (10)
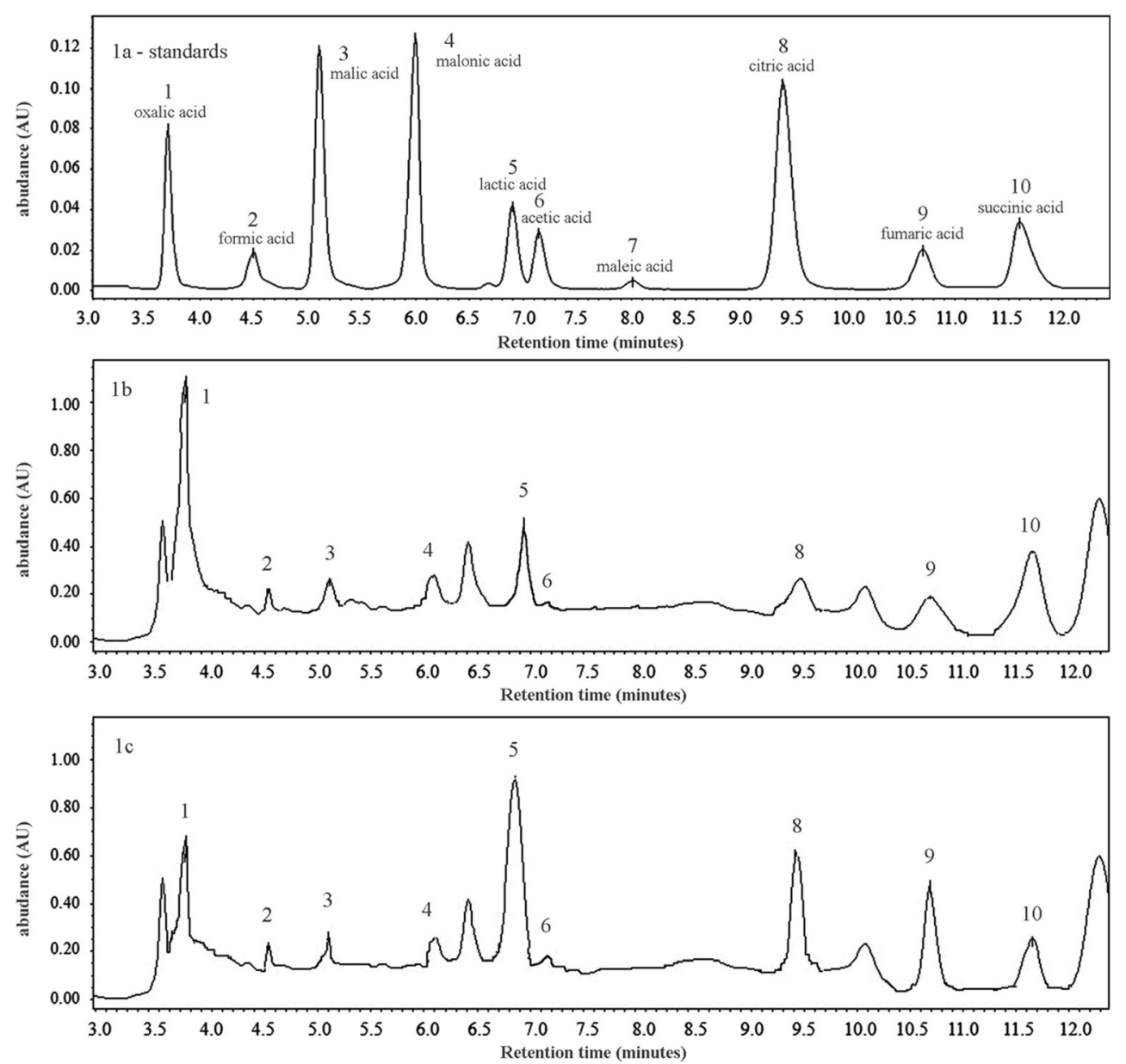

$\mathrm{Pb}$, and $\mathrm{Se}$, while malonic and malic acids show a highly positive correlation with $\mathrm{Ba}$ and $\mathrm{Mn}$. On the other hand, a highly negative correlation was observed between malic acid and $\mathrm{Al}, \mathrm{B}, \mathrm{Ca}, \mathrm{Ce}, \mathrm{Er}, \mathrm{Hg}, \mathrm{Mg}, \mathrm{Nd}, \mathrm{Pb}, \mathrm{Sb}, \mathrm{Se}, \mathrm{Sr}$, and $\mathrm{Te}$; malonic acid and $\mathrm{Ca}, \mathrm{Mg}$, and $\mathrm{Nd}$; and citric acid and $\mathrm{Ba}$ and Mn. However, this initial survey of relations between numerous elements and LMWOAs content in fruiting bodies of one mushroom species will need further comprehensive research.
Table 5 Low-molecular-weight organic acid content and composition ( $\left.\mathrm{mg} \mathrm{g}^{-1} \mathrm{DW}\right)$ in Boletus badius fruit bodies collected from unpolluted and polluted areas

\begin{tabular}{llllll}
\hline Organic acids & \multicolumn{2}{l}{ Unpolluted area } & & \multicolumn{2}{l}{ Polluted area } \\
\cline { 2 - 3 } \cline { 5 - 6 } & Site 1 & Site 2 & & Site 3 & Site 4 \\
\hline Acetic acid & $0.04^{\mathrm{b}} \pm 0.00$ & $0.03^{\mathrm{b}} \pm 0.01$ & & $0.07^{\mathrm{a}} \pm 0.01$ & $0.07^{\mathrm{a}} \pm 0.01$ \\
Citric acid & $0.50^{\mathrm{b}} \pm 0.050$ & $0.56^{\mathrm{b}} \pm 0.203$ & & $5.41^{\mathrm{a}} \pm 0.596$ & $4.61^{\mathrm{a}} \pm 0.29$ \\
Formic acid & $0.18^{\mathrm{ab}} \pm 0.02$ & $0.15^{\mathrm{ab}} \pm 0.01$ & & $0.19^{\mathrm{a}} \pm 0.03$ & $0.12^{\mathrm{b}} \pm 0.02$ \\
Fumaric acid & $0.01^{\mathrm{a}} \pm 0.00$ & $0.17^{\mathrm{a}} \pm 0.11$ & & $0.02^{\mathrm{a}} \pm 0.00$ & $0.02^{\mathrm{a}} \pm 0.00$ \\
Lactic acid & $7.17^{\mathrm{b}} \pm 0.61$ & $9.60^{\mathrm{b}} \pm 1.53$ & & $11.2^{\mathrm{ab}} \pm 1.7$ & $14.8^{\mathrm{a}} \pm 2.0$ \\
Maleic acid & $n d$ & & & $n d$ & $n$ \\
Malic acid & $0.43^{\mathrm{b}} \pm 0.04$ & $0.43^{\mathrm{b}} \pm 0.08$ & & $0.06^{\mathrm{a}} \pm 0.01$ & $0.06^{\mathrm{a}} \pm 0.01$ \\
Malonic acid & $0.95^{\mathrm{a}} \pm 0.09$ & $1.05^{\mathrm{a}} \pm 0.24$ & & $0.26^{\mathrm{b}} \pm 0.05$ & $0.29^{\mathrm{b}} \pm 0.04$ \\
Oxalic acid & $1.37^{\mathrm{a}} \pm 0.14$ & $1.01^{\mathrm{b}} \pm 0.01$ & & $0.74^{\mathrm{b}} \pm 0.07$ & $0.37^{\mathrm{c}} \pm 0.11$ \\
Succinic acid & $8.88^{\mathrm{a}} \pm 0.333$ & $5.30^{\mathrm{b}} \pm 0.38$ & & $4.23^{\mathrm{b}} \pm 0.60$ & $2.88^{\mathrm{c}} \pm 0.67$ \\
Total content of identified acids & $19.5^{\mathrm{a}} \pm 1.1$ & $18.3^{\mathrm{a}} \pm 2.5$ & & $22.2^{\mathrm{a}} \pm 1.4$ & $23.2^{\mathrm{a}} \pm 3.2$ \\
\hline
\end{tabular}

Mean values $(n=5) \pm$ standard deviations; identical superscripts denote significant $(p<0.05)$ difference between mean values in lines according to Tukey's HSD test (ANOVA) for whole fruit bodies

$n d$ not detected 
Table 6 Pearson correlation coefficients $(r)$ between content of particular low-molecular-weight organic acid and element in Boletus badius fruit bodies

\begin{tabular}{|c|c|c|c|c|c|c|c|c|c|c|}
\hline \multirow[t]{2}{*}{ Element } & \multicolumn{10}{|c|}{ Low-molecular-weight organic acid } \\
\hline & Acetic & Citric & Formic & Fumaric & Lactic & Malic & Malonic & Oxalic & Succinic & Total \\
\hline $\mathrm{Al}$ & $0.9069 *$ & $0.9635^{*}$ & -0.1123 & -0.4725 & $0.6901 *$ & $-0.9250 *$ & $-0.8964^{*}$ & $-0.7508^{*}$ & $-0.6786^{*}$ & $0.6761 *$ \\
\hline As & $0.8311^{*}$ & $0.9200 *$ & 0.2294 & -0.4394 & 0.4274 & $-0.8150 *$ & $-0.7910^{*}$ & -0.5133 & -0.4755 & 0.5736 \\
\hline B & $0.9012 *$ & $0.9480^{*}$ & -0.2458 & -0.4121 & $0.7603 *$ & $-0.9362 *$ & $-0.8912 *$ & $-0.8418^{*}$ & $-0.7536^{*}$ & $0.6701 *$ \\
\hline $\mathrm{Ba}$ & $-0.8236^{*}$ & $-0.9368^{*}$ & 0.1988 & 0.2956 & $-0.7043^{*}$ & $0.9506^{*}$ & $0.9027 *$ & $0.8726^{*}$ & $0.8107 *$ & -0.5543 \\
\hline $\mathrm{Ca}$ & $0.8963 *$ & $0.9940 *$ & -0.0653 & -0.395 & $0.6749 *$ & $-0.9607 *$ & $-0.9246^{*}$ & $-0.7897 *$ & $-0.7371 *$ & $0.6299 *$ \\
\hline $\mathrm{Cd}$ & $0.6742 *$ & $0.6782^{*}$ & 0.3184 & -0.4529 & 0.2390 & -0.5317 & -0.5239 & -0.2109 & -0.1745 & 0.5092 \\
\hline $\mathrm{Ce}$ & $0.9007 *$ & $0.9905^{*}$ & -0.0234 & -0.3852 & $0.6391 *$ & $-0.9373 *$ & $-0.8950^{*}$ & $-0.7567 *$ & $-0.7048 *$ & $0.6242 *$ \\
\hline Co & $0.8863^{*}$ & $0.9754^{*}$ & 0.0543 & -0.3448 & $0.6028 *$ & $-0.8945^{*}$ & $-0.8505^{*}$ & $-0.6993 *$ & $-0.6792 *$ & $0.6114 *$ \\
\hline $\mathrm{Cr}$ & 0.0179 & 0.0606 & 0.3911 & 0.2976 & -0.1477 & 0.1174 & 0.1433 & 0.1753 & -0.0290 & -0.0717 \\
\hline $\mathrm{Cu}$ & -0.4822 & -0.5202 & 0.3766 & 0.4049 & -0.5130 & $0.6525 *$ & $0.6443 *$ & $0.6323^{*}$ & 0.4468 & -0.3852 \\
\hline Dy & $0.8729 *$ & $0.8694^{*}$ & -0.3241 & -0.2923 & $0.7967 *$ & $-0.8375^{*}$ & $-0.7782 *$ & $-0.8344^{*}$ & $-0.7774 *$ & $0.6547^{*}$ \\
\hline Er & $0.9163^{*}$ & $0.9691^{*}$ & -0.1896 & -0.3834 & $0.7423 *$ & $-0.9419 *$ & $-0.8933^{*}$ & $-0.8369 *$ & $-0.7623^{*}$ & $0.6617 *$ \\
\hline $\mathrm{Eu}$ & 0.5073 & $0.6455^{*}$ & 0.5470 & -0.1891 & 0.0530 & -0.4832 & -0.4708 & -0.1451 & -0.2220 & 0.2756 \\
\hline $\mathrm{Fe}$ & 0.5178 & 0.4429 & -0.3837 & -0.0009 & $0.5763 *$ & -0.3772 & -0.3163 & -0.5416 & -0.5733 & 0.3806 \\
\hline Gd & $0.7379 *$ & $0.6418^{*}$ & -0.3567 & -0.5461 & $0.6465 *$ & $-0.6578 *$ & $-0.6370^{*}$ & $-0.5966^{*}$ & -0.4146 & $0.6502 *$ \\
\hline $\mathrm{Hg}$ & $0.8844^{*}$ & $0.9406^{*}$ & -0.1737 & -0.4652 & $0.7008 *$ & $-0.9162 *$ & $-0.8809 *$ & $-0.7667 *$ & $-0.6793 *$ & $0.6693 *$ \\
\hline $\mathrm{K}$ & 0.2679 & 0.0412 & -0.3146 & -0.0805 & 0.3771 & 0.0057 & 0.0439 & -0.1392 & 0.0601 & 0.4669 \\
\hline $\mathrm{La}$ & -0.5123 & -0.5516 & 0.3357 & 0.4467 & -0.5039 & $0.6748 *$ & $0.6693^{*}$ & $0.6211^{*}$ & 0.4293 & -0.4094 \\
\hline $\mathrm{Li}$ & -0.2105 & -0.3864 & 0.1812 & -0.3759 & -0.3709 & 0.4113 & 0.3496 & $0.5828^{*}$ & $0.7184 *$ & -0.0041 \\
\hline $\mathrm{Lu}$ & $0.8990 *$ & $0.9303^{*}$ & -0.0548 & -0.3910 & $0.6454 *$ & $-0.8522 *$ & $-0.8083^{*}$ & $-0.6943 *$ & $-0.6435^{*}$ & $0.6562 *$ \\
\hline $\mathrm{Mg}$ & $0.8864 *$ & $0.9890^{*}$ & -0.0163 & -0.4147 & $0.6492 *$ & $-0.9474 *$ & $-0.9170^{*}$ & $-0.7444 *$ & $-0.6953 *$ & $0.6384 *$ \\
\hline $\mathrm{Mn}$ & $-0.8253^{*}$ & $-0.9095^{*}$ & 0.1385 & 0.4898 & $-0.6267 *$ & $0.9339 *$ & $0.9082 *$ & $0.7647 *$ & $0.6330^{*}$ & $-0.5964 *$ \\
\hline Mo & $0.8669 *$ & $0.9665 *$ & 0.1303 & -0.4075 & 0.5207 & $-0.8836^{*}$ & $-0.8507^{*}$ & $-0.6309^{*}$ & $-0.5919 *$ & $0.5922 *$ \\
\hline $\mathrm{Na}$ & $0.8257^{*}$ & $0.9377^{*}$ & 0.0634 & -0.4254 & 0.5515 & $-0.8744 *$ & $-0.8518^{*}$ & $-0.6249 *$ & -0.5637 & $0.6245^{*}$ \\
\hline $\mathrm{Nd}$ & $0.9003^{*}$ & $0.9934 *$ & -0.0314 & -0.3925 & $0.6697 *$ & $-0.9518 *$ & $-0.9149 *$ & $-0.7647 *$ & $-0.7156^{*}$ & $0.6461 *$ \\
\hline $\mathrm{Ni}$ & -0.4919 & -0.5733 & 0.5347 & 0.0324 & $-0.6944^{*}$ & $0.6880 *$ & $0.6347 *$ & $0.8622 *$ & $0.8066^{*}$ & -0.3218 \\
\hline $\mathrm{P}$ & -0.4590 & -0.5565 & 0.5478 & -0.0187 & $-0.6906^{*}$ & $0.6599 *$ & $0.6049 *$ & $0.8630^{*}$ & $0.8310^{*}$ & -0.2926 \\
\hline $\mathrm{Pb}$ & 0.9101* & $0.9627^{*}$ & -0.1878 & -0.3311 & $0.7470^{*}$ & $-0.9232 *$ & $-0.8693^{*}$ & $-0.8373^{*}$ & $-0.7855^{*}$ & $0.6499 *$ \\
\hline $\mathrm{Sb}$ & $0.8894 *$ & $0.9865^{*}$ & 0.0386 & -0.3996 & $0.5926^{*}$ & $-0.9242 *$ & $-0.8862 *$ & $-0.7117 *$ & $-0.6624 *$ & $0.6119^{*}$ \\
\hline $\mathrm{Sc}$ & $0.8274 *$ & $0.9037^{*}$ & 0.0507 & -0.2260 & 0.5697 & $-0.7956^{*}$ & $-0.7437 *$ & $-0.6492 *$ & $-0.6737 *$ & 0.5547 \\
\hline $\mathrm{Se}$ & $0.9118^{*}$ & $0.9497 *$ & -0.2463 & -0.3979 & $0.7666^{*}$ & $-0.9362 *$ & $-0.8880^{*}$ & $-0.8521 *$ & $-0.7619 *$ & $0.6712 *$ \\
\hline $\mathrm{Sr}$ & $0.8793 *$ & $0.9844 *$ & 0.0590 & -0.3835 & $0.5775^{*}$ & $-0.9189 *$ & $-0.8807^{*}$ & $-0.7027 *$ & $-0.6616^{*}$ & $0.5976^{*}$ \\
\hline $\mathrm{Te}$ & $0.8930 *$ & $0.9887^{*}$ & 0.0194 & -0.3995 & $0.6063 *$ & $-0.9309 *$ & $-0.8920^{*}$ & $-0.7264 *$ & $-0.6742 *$ & $0.6159 *$ \\
\hline $\mathrm{Zn}$ & 0.5709 & $0.6731^{*}$ & 0.2972 & 0.1973 & 0.3570 & -0.4731 & -0.3995 & -0.3913 & -0.4932 & 0.4010 \\
\hline
\end{tabular}

* Significant at $p<0.05$

\section{Conclusions}

The accumulation of elements in mushroom species is diverse as regards the place (element concentration in substrate), where fruiting bodies are grown. The obtained results have revealed the existence of relationships between content of elements and low-molecular-weight organic acids in $B$. badius. The significantly higher content of the majority of elements in mushrooms growing on flotation tailings than in soil was related with higher acid contents thereby proving that these acids play a significant role in element uptake. The higher content of citric acids in fruiting bodies growing on the polluted substrate allows us to state that mushrooms are able to grow in a polluted area; therefore, a high level of citric acid content in substrate could be associated with a more effective removal of elements from the environment, e.g., using plants. 
Acknowledgments The authors would like to thank KGHM Polska Miedź S.A. for the delivery of experimental materials (flotation tailings).

Open Access This article is distributed under the terms of the Creative Commons Attribution 4.0 International License (http:// creativecommons.org/licenses/by/4.0/), which permits unrestricted use, distribution, and reproduction in any medium, provided you give appropriate credit to the original author(s) and the source, provide a link to the Creative Commons license, and indicate if changes were made.

\section{References}

Barros L, Pereira C, Ferreira ICFR (2013) Optimized analysis of organic acids in edible mushrooms from Portugal by ultra fast liquid chromatography and photodiode array detection. Food Anal Methods 6: 309-316

Blake L, Goulding KWT (2002) Effects of atmospheric deposition, soil $\mathrm{pH}$ and acidification on heavy metal contents in soils and vegetation of semi-natural ecosystems at Rothamsted Experimental Station, UK. Plant Soil 240:235-251

Borovička J, Řanda Z (2007) Distribution of iron, cobalt, zinc and selenium in macrofungi. Mycol progress. 6:249-259

Böke N, Sirén H, Petrik LF (2015) Fungal biofermentation of pine bark producing organic acids and their quantification with capillary electrophoresis. Ind Crop Prod 67:41-48

Campos JA, Tejera NA (2011) Bioconcentration factors and trace elements bioaccumulation in sporocarps of fungi collected from quartzite acidic soils. Biol Trace Elem Res 143:540-554

Cawthray GR (2003) An improved reversed-phase liquid chromatographic method for the analysis of low-molecular mass organic acids in plant root exudates. J Chromatogr A 1011:233-240

Dresler S, Bednarek W, Wójcik M (2014) Effect of cadmium on selected physiological and morphological parameters in metallicolous and non-metallicolous populations of Echium vulgare L. Ecotoxicol Environ Saf 104:332-338

Drzewiecka K, Mleczek M, Gąsecka M, Magdziak Z, Chadzinikolau T, Goliński P (2014) Copper phytoextraction with Salix purpurea $\times$ viminalis under various $\mathrm{Ca} / \mathrm{Mg}$ ratios. Part 2. Effect on organic acid, phenolics and salicylic acid contents. Acta Physiol Plant 36:903913

Falandysz J (2008) Selenium in edible mushrooms. J Environ Sci Heal C $26: 256-299$

Falandysz J, Bielawski L (2007) Mercury and its bioconcentration factors in Brown birch Scaber stalk (Leccinum scabrum) from various sites in Poland. Food Chem 105:635-640

Falandysz J, Borovička J (2013) Macro and trace mineral constituents and radionuclides in mushrooms: health benefits and risks. Appl Microbiol Biotechnol 97:477-501

Falandysz J, Szymczyk K, Ichihashi H, Bielawksi L, Gucia M, Frankowska A, Yamasaki S-I (2001) ICP/MS and ICP/AES elemental analysis (38 elements) of edible wild mushrooms growing in Poland. Food Addit Contam 18:503-513

Fernandes Â, Barreira JCM, Antonio AL, Oliveira MBPP, Martins A, Ferreira ICFR (2014) Feasibility of electron-beam irradiation to preserve wild dried mushrooms: effects on chemical composition and antioxidant activity. Innovative Food Sci Emerg 22:158-166

Gadd GM (1999) Fungal production of citric and oxalic acid: importance in metal speciation, physiology and biogeochemical processes. Adv Microb Physiol 41:47-92

Ghnaya T, Zaier H, Baioui R, Sghaier S, Lucchini G, Sacchi GA, Lutts S, Abdelly C (2013) Implication of organic acids in the long-distance transport and the accumulation of lead in Sesuvium portulacastrum and Brassica juncea. Chemosphere 90:1449-1454

Goliński P, Mleczek M, Magdziak Z, Gąsecka M, Borowiak K, Dąbrowski J, Kaczmarek Z, Rutkowski P (2015) Efficiency of Zn phytoextraction, biomass yield and formation of low-molecularweight organic acids in $S \times$ rubens - a hydroponic experiment. Chem Ecol 31:345-364

ISO 10390 (2005) Soil quality-determination of $\mathrm{pH}$

ISO 11271 (2002) Soil quality - determination of redox potential

Kalač P (2010) Trace element contents in European species of wild growing edible mushrooms: a review for the period 2000-2009. Food Chem 122:2-15

Karaffa L, Sándor E, Fekete E, Szentirmai A (2001) The biochemistry of citric acid accumulation by Aspergillus niger. Acta Microbiol Immunol Hung 48:429-440

Kojta AK, Jarzyńska G, Falandysz J (2012) Mineral composition and heavy metal accumulation capacity of bay bolete (Xerocomus badius) fruiting bodies collected near a former gold and copper mining area. J Geochem Explor 121:76-82

Kutrowska A, Szelag M (2014) Low-molecular weight organic acids and peptides involved in the long-distance transport of trace metals. Acta Physiol Plant 36:1957-1968

Leal AR, Barros L, Barreira JCM, Sousa MJ, Martins A, Santos-Buelga C, Ferreira ICFR (2013) Portuguese wild mushrooms at the "pharma-nutrition" interface: nutritional characterization and antioxidant properties. Food Res Int 50:1-9

López-Bucio J, Nieto-Jacobo MF, Ramírez-Rodríguez V, Herrera-Estrella L (2000) Review organic acid metabolism in plants: from adaptive physiology to transgenic varieties for cultivation in extreme soils. Plant Sci 160:1-13

Magdziak Z, Mleczek M, Kaczmarek Z, Goliński P (2013) Influence of $\mathrm{Ca} / \mathrm{Mg}$ ratio and $\mathrm{Cd}^{2+}$ and $\mathrm{Pb}^{2+}$ elements on low molecular weight organic acid secretion by Salix viminalis L. Roots into the rhizosphere. Trees Struct Funct 27:663-673

Malinowska E, Szefer P, Falandysz J (2004) Metals bioaccumulation by bay bolete, Xerocomus badius, from selected sites in Poland. Food Chem 84:405-416

Mleczek M, Siwulski M, Mikołajczak P, Gąsecka M, Sobieralski K, Szymańczyk M, Goliński P (2015b) Content of selected elements in Boletus badius fruiting bodies growing in extremely polluted wastes. J Environ Sci Healt A 50:767-775

Mleczek M, Siwulski M, Mikołajczak P, Goliński P, Gasecka M, Sobieralski K, Dawidowicz L, Szymańczyk M (2015a) Bioaccumulation of elements in three selected mushroom species from Southwest Poland. J Environ Sci Healt B 50:207-216

Nawirska-Olszańska A, Biesiada A, Sokół-Łętowska A, Kucharska AZ (2014) Characteristics of organic acids in the fruit of different pumpkin species. Food Chem 148:415-419

Niedzielski P, Mleczek M, Magdziak Z, Siwulski M, Kozak L (2013) Selected arsenic species: as(III), as(V) and dimethylarsenic acid (DMAA) in Xerocomus badius fruiting bodies. Food Chem 141: 3571-3577

Ousmanova D, Parker W (2007) Fungal generation of organic acids for removal of lead from contaminated soil. Water Air Soil Pollut 179: $365-380$

Reczyński W, Muszyńska B, Opoka W, Smalec A, Sułkowska-Ziaja K, Malec M (2013) Comparative study of metals accumulation in cultured in vitro mycelium and naturally grown fruiting bodies of Boletus badius and Cantharellus cibarius. Biol Trace Elem Res 153:355-362

Regulation of the Ministry of Economy (2015) No. 110, concerning kinds of wastes maybe stored at landfills of wastes in nonselective way

Ribeiro B, Andrade PB, Baptista P, Barros L, Ferreira ICFR, Seabra RM, Valentão P (2008) Leucopaxillus giganteus mycelium: effect of nitrogen source on organic acids and alkaloids. J Agric Food Chem 56:4769-4774 
Ribeiro B, Rangel J, Valentão P, Baptista P, Seabra RM, Andrade PB (2006) Contents of carboxylic acids and two phenolics and antioxidant activity of dried Portuguese wild edible mushrooms. J Agric Food Chem 54:8530-8537

Rudawska M, Leski T (2005) Macro- and microelement contents in fruiting bodies of wild mushrooms from the Notecka forest in west-Central Poland. Food Chem 92:499-506

Svoboda L, Chrastný V (2008) Levels of eight trace elements in edible mushrooms from a rural area. Food Addit Contam Part A 25: $51-58$
Svoboda L, Havlíčková B, Kalač P (2006) Contents of cadmium, mercury and lead in edible mushrooms growing in a historical silvermining area. Food Chem 96:580-585

Tyler G, Olsson T (2001) Concentrations of 60 elements in the soil solution as related to the soil acidity. Eur J Soil Sci 52:151-165

Zeppa S, Amicucci A, Saltarelli R, Giomaro G, Stocchi V (2012) Edible ectomycorrhizal mushroom molecular response to heavy metals. In: Zambonelli A, Bonito GM (eds) Edible ectomycorrhizal mushrooms, soil biology, vol 34. Springer-Verlag, Berlin Heidelberg, pp. $41-46$ 